\title{
Influence of Climate on Google Internet Searches for Pruritus Across 16 German Cities: Retrospective Analysis
}

Linda Tizek ${ }^{1,2}$, MPH; Maximilian Schielein ${ }^{1,2}$, MPH; Melvin Rüth ${ }^{1}$, BSc; Sonja Ständer ${ }^{3}$, MD; Manuel Pedro Pereira ${ }^{3}$, MD; Bernadette Eberlein ${ }^{1}$, MD; Tilo Biedermann ${ }^{1}$, MD; Alexander Zink ${ }^{1}$, MPH, MD, PhD

\footnotetext{
${ }^{1}$ Department of Dermatology and Allergy, School of Medicine, Technical University of Munich, Munich, Germany

${ }^{2}$ The Institute for Medical Information Processing, Biometry, and Epidemiology, Ludwig Maximilian University Munich, Munich, Germany

${ }^{3}$ Center for Chronic Pruritus, Department of Dermatology, University Hospital Münster, Muenster, Germany
}

\section{Corresponding Author:}

Alexander Zink, MPH, MD, PhD

Department of Dermatology and Allergy

School of Medicine

Technical University of Munich

Biedersteiner Str 29

Munich, 80802

Germany

Phone: 498941403038

Fax: 498941403552

Email: Alexander.zink@tum.de

\section{Abstract}

Background: The burden of pruritus is high, especially among patients with dermatologic diseases. Identifying trends in pruritus burden and people's medical needs is challenging, since not all affected people consult a physician.

Objective: The purpose of this study was to investigate pruritus search behavior trends in Germany and identify associations with weather factors.

Methods: Google AdWords Keyword Planner was used to quantify pruritus-related search queries in 16 German cities from August 2014 to July 2018. All identified keywords were qualitatively categorized and pruritus-related terms were descriptively analyzed. The number of search queries per 100,000 inhabitants of each city was compared to environmental factors such as temperature, humidity, particulate matter 10 micrometers or less in diameter (PM10), and sunshine duration to investigate potential correlations.

Results: We included 1150 pruritus-related keywords, which resulted in 2,851,290 queries. "Pruritus" $(\mathrm{n}=115,680)$ and "anal pruritus" ( $\mathrm{n}=102,390)$ were the most-searched-for keywords. Nearly half of all queries were related to the category localization, with Berlin and Munich having a comparatively high proportion of people that searched for pruritus in the genital and anal areas. People searched more frequently for information on chronic compared to acute pruritus. The most populated cities had the lowest number of queries per 100,000 inhabitants (Berlin, $n=13,641$; Hamburg, $n=18,303$; and Munich, $n=21,363$ ), while smaller cities (Kiel, $n=35,027$; and Freiburg, $n=39,501$ ) had the highest. Temperature had a greater effect on search query number (beta -7.94 , 95\% CI - 10.74 to -5.15 ) than did PM10 (beta $-5.13,95 \%$ CI -7.04 to -3.22 ), humidity (beta $4.73,95 \%$ CI 2.70 to 6.75 ), or sunshine duration (beta $0.66,95 \% \mathrm{CI} 0.36$ to 0.97 ). The highest relative number of search queries occurred during the winter (ie, December to February).

Conclusions: By taking into account the study results, Google data analysis helps to examine people's search frequency, behavior, and interest across cities and regions. The results indicated a general increase in search queries during the winter as well as differences across cities located in the same region; for example, there was a decline in search volume in Saarbrucken, while there were increases in Cologne, Frankfurt, and Dortmund. In addition, the detected correlation between search volume and weather data seems to be valuable in predicting an increase in pruritus burden, since a significant association with rising humidity and sunshine duration, as well as declining temperature and PM10, was found. Accordingly, this is an unconventional and inexpensive method to identify search behavior trends and respective inhabitants' needs. 


\section{KEYWORDS}

pruritus; Internet; informatics; environment; weather; retrospective studies

\section{Introduction}

Pruritus is one of the most common presenting symptoms in dermatological patients, appearing in more than $50 \%$ of patients $[1,2]$. In general, acute and chronic pruritus occurrences are most prevalent among people affected by scabies (up to $100 \%$ ) [3], atopic dermatitis (83.3\%-91.0\%) [2,4,5], and psoriasis (48.6\%-84.0\%) [5,6]. Epidemiological studies have reported point prevalence rates in the general population ranging from $3.6 \%$ to $8.4 \%$ for acute pruritus $[1,5]$ and $13.5 \%$ to $31.2 \%$ for chronic pruritus (ie, lasting $>6$ weeks) $[2,7,8]$. Prevalence has been observed to increase with age [9].

Pruritus can have a great impact on quality of life [10-12]. There is a higher prevalence of suicidal ideation and depression among people with severe pruritus $[11,13,14]$. Treatment, especially for chronic pruritus, can be very challenging owing to the diversity of underlying diseases $[15,16]$, subjective sensations, and varying individual patient needs $[17,18]$. There are various scales for measuring symptom intensity and severity [19]. Pruritus is also measured using patient-oriented measurements (eg, the patient benefit index) according to the individual needs and desires of patients with respect to therapeutic outcomes [20]. A study that used the patient benefit index showed that $83.9 \%$ of patients with psoriasis considered the reduction of pruritus to be a treatment goal [21]. However, people with less severe pruritus, localized manifestations, or only occasional itching might not seek professional health care; thus, it is challenging to examine people's interest in medical needs.

An unconventional method to assess people's interest in different aspects of pruritus outside the medical setting is to analyze the volume of Internet searches for "pruritus" and accompanying expressions, since the Internet is a commonly used source of health information [22,23]. In Germany, $90 \%$ of residents use the Internet and $72 \%$ use it daily [24]. Approximately 57\% of the German population have used the Internet to search for health-related information at least once [25] and the vast majority of this group (95\%) use Google as their primary search engine [26]. As previously demonstrated, Google data analysis is valuable for detecting seasonal trends and making forecasts regarding various diseases, such as cancer, epilepsy, Ebola virus disease, or influenza [27-29]. For example, as previously demonstrated in the United States, search behavior was associated with incidence rates of various tumors (eg, skin cancer) [29] or coronary heart disease. In addition, analyzing Internet data is useful for examining Internet behavior, interest, and people's reactions to various incidents [27]. Studies investigating Google search volume data for the term "pruritus" in Germany have demonstrated that this method provides good insight into people's interests and needs [30,31]. However, dermatological care differs even within Germany. For example, according to the German Association of Panel Doctors (Kassenärztliche Bundesvereinigung), the supply of dermatologists (ie, the proportion of target to actual number of dermatologists as a function of regional inhabitants) was comprehensively higher in Freiburg (218.2\%) and Kiel (188.1\%) than in Berlin (124.1\%) and Hamburg (113.3\%) [32]. Besides variations in the supply of dermatologists, there are regional differences in environmental triggers, such as temperature [33-37]. Accordingly, further analysis of Google data with regard to regional differences in pruritus would be valuable. Therefore, in an effort to identify possible unmet needs, this study examined the Google search volume data of 16 German cities to investigate whether there were local differences in people's interest in pruritus and whether external factors might have had an influence on search behavior.

\section{Methods}

\section{Study Design}

A retrospective longitudinal study using Google AdWords Keyword Planner was conducted to identify the Google search volume of keywords related to pruritus in 16 cities across Germany. Four cities each from Northern Germany (Hamburg, Hannover, Kiel, and Rostock), Eastern Germany (Berlin, Leipzig, Dresden, and Magdeburg), Southern Germany (Munich, Stuttgart, Nuremberg, and Freiburg), and Western Germany (Cologne, Frankfurt, Dortmund, and Saarbrucken) were chosen for a representative evaluation to determine whether there are national and geographical differences in pruritus searches within these regions. Most of the cities were chosen because they are Germany's largest cities by population; the following 11 cities are listed in order of largest population to smallest, with their population ranking in Germany within parentheses: Berlin (1), Hamburg (2), Munich (3), Cologne (4), Frankfurt (5), Stuttgart (6), Dortmund (8), Leipzig (9), Dresden (12), Hannover (13), and Nuremberg (14). Furthermore, Kiel and Rostock were chosen to examine whether the proximity to the coast has an influence on Google search volume. The remaining cities_Freiburg, Saarbrucken, and Magdeburg — were chosen because we wanted to have a nationwide overview about various regions and they are three of the largest cities within these regions. Even though the main function of Google's Keyword Planner is to optimize advertising, it can also be used to answer scientific questions $[23,30,31]$. To assess search volume within a specific field, words or phrases related to the topic are initially entered into the tool. The Keyword Planner then finds the most relevant search terms. For each identified keyword, the tool provides the monthly search volume data as estimated by Google, which are available for the last 48 months. The search volume represents the total number of searches related to selected keywords [38]. In this study, the tool was used to investigate the number of search queries associated with the German lay word for pruritus or itch ("Juckreiz") from August 2014 to July 2018 (see Figure 1). The region and language settings were set so that the search volume data using Google products were limited solely to users in the abovementioned cities whose language preference was German.

Since the study was based on Google search terms, institutional review board approval was not needed and informed consent was not applicable. 
Figure 1. Map showing the 16 German cities for which Google search volume analysis was performed for pruritus-related terms searched from August 2014 to July 2018. n: number of search queries per 100,000 inhabitants; d: supply of dermatologists (ie, ratio of target to actual number of dermatologists with respect to population).

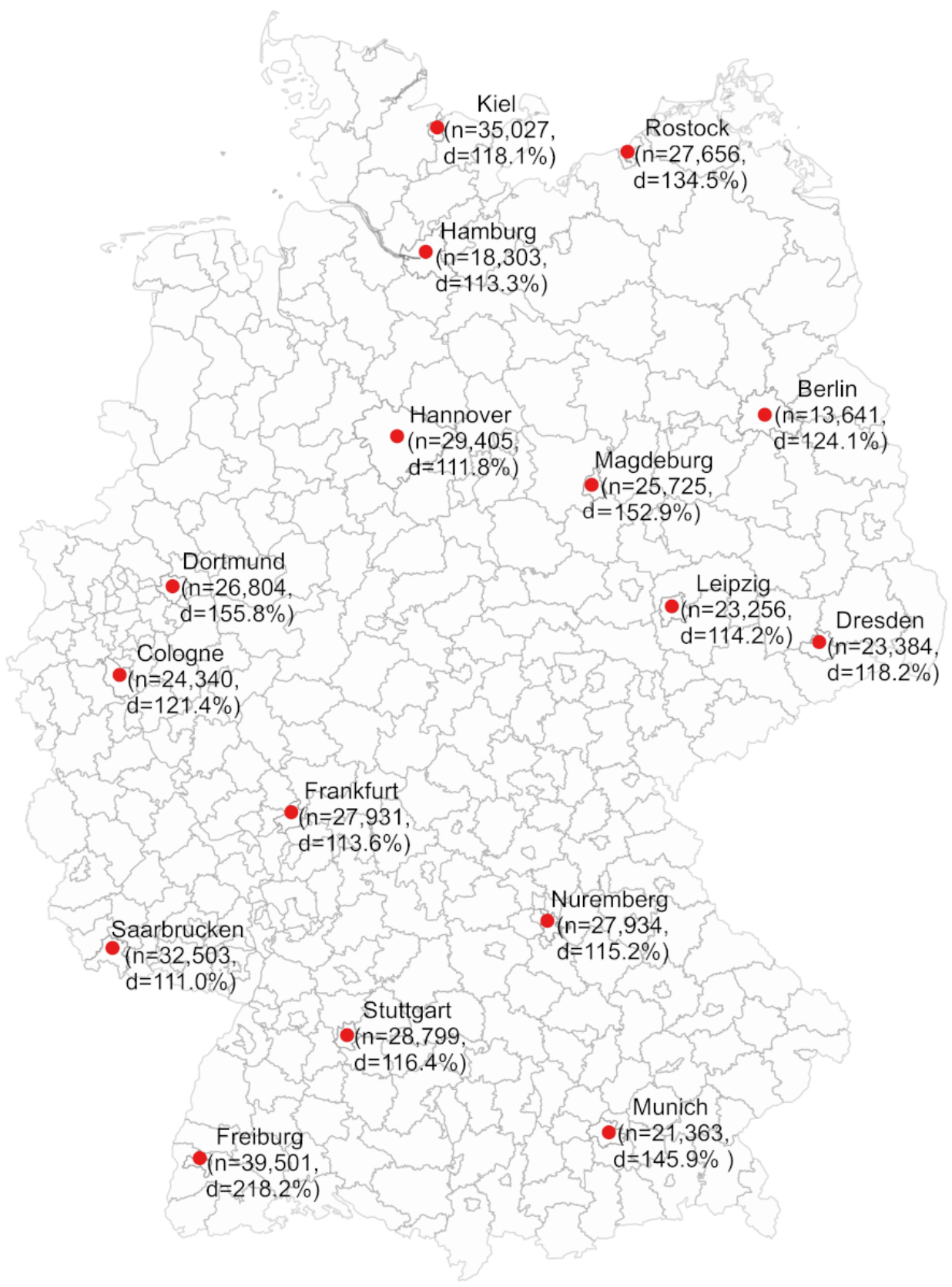

\section{Classifications}

Keywords identified by Google AdWords Keyword Planner were qualitatively analyzed. Terms that were associated with pruritus but did not explicitly include words or phrases related to pruritus (eg, "psoriasis" and "atopic dermatitis") were initially excluded from descriptive analyses. Only when investigating a correlation between the supply of general practitioners (GPs) and search volume were these terms considered, as people consulting a GP might receive other less-specific diagnoses [36]. After qualitatively assessing all pruritus-related keywords, eight categories were formed in accordance with previous studies $[30,31]$ to determine differences in people's interests: causes (eg, "pruritus causes"), conditions (eg, "pruritus at night-time"), influential factors (eg, "allergic pruritus"), localization (eg, "itchy legs"), pruritus descriptors (eg, "strong pruritus"), questions on pruritus (eg, "what causes pruritus?"), and treatment (eg, "drugs against pruritus"); searches that did not fit any of these categories were placed in a general category (eg, "pruritus"). Terms matching several criteria were assigned to multiple categories. To assess differences in search behaviors across Germany, the search volume for each city was calculated in relation to its inhabitants [39] and then expressed as the number of search queries per 100,000 inhabitants (see Table 1). 
Table 1. Number of searches per 100,000 inhabitants according to categories of pruritus-related keywords in 16 German cities from August 2014 to July 2018.

\begin{tabular}{|c|c|c|c|c|c|c|c|c|c|}
\hline \multirow{2}{*}{$\begin{array}{l}\text { City (overall } \\
\text { search volume) }^{\mathrm{a}} \\
{[39]}\end{array}$} & \multirow{2}{*}{$\begin{array}{l}\text { Number of } \\
\text { inhabitants } \\
\text { in } 2016\end{array}$} & \multicolumn{8}{|c|}{ Categories and number of searches $/ 100,000$ inhabitants, $\mathrm{n}(\%)^{\mathrm{b}}$} \\
\hline & & $\begin{array}{l}\text { Causes } \\
\left(\mathrm{k}^{\mathrm{c}}=94\right)\end{array}$ & $\begin{array}{l}\text { Conditions } \\
(\mathrm{k}=148)\end{array}$ & $\begin{array}{l}\text { Influential } \\
\text { factors } \\
(\mathrm{k}=240)\end{array}$ & $\begin{array}{l}\text { Localization } \\
(\mathrm{k}=499)\end{array}$ & $\begin{array}{l}\text { Pruritus } \\
\text { descriptors } \\
(\mathrm{k}=215)\end{array}$ & $\begin{array}{l}\text { Questions on } \\
\text { pruritus } \\
(\mathrm{k}=100)\end{array}$ & $\begin{array}{l}\text { Treatment } \\
(\mathrm{k}=149)\end{array}$ & $\begin{array}{l}\text { General } \\
(\mathrm{k}=109)\end{array}$ \\
\hline $\begin{array}{l}\text { Berlin } \\
(\mathrm{N}=13,641)\end{array}$ & $3,574,830$ & $\begin{array}{l}779 \\
(5.71)\end{array}$ & $\begin{array}{l}1128 \\
(8.27)\end{array}$ & $\begin{array}{l}1966 \\
(14.41)\end{array}$ & $\begin{array}{l}6119 \\
(44.86)\end{array}$ & $\begin{array}{l}1537 \\
(11.27)\end{array}$ & $\begin{array}{l}720 \\
(5.28)\end{array}$ & $\begin{array}{l}1475 \\
(10.82)\end{array}$ & $\begin{array}{l}2674 \\
(19.60)\end{array}$ \\
\hline $\begin{array}{l}\text { Hamburg } \\
(\mathrm{N}=18,303)\end{array}$ & $1,810,438$ & $\begin{array}{l}1058 \\
(5.78)\end{array}$ & $\begin{array}{l}1665 \\
(9.10)\end{array}$ & $\begin{array}{l}2891 \\
(15.80)\end{array}$ & $\begin{array}{l}8083 \\
(44.16)\end{array}$ & $\begin{array}{l}2156 \\
(11.78)\end{array}$ & $\begin{array}{l}1012 \\
(5.53)\end{array}$ & $\begin{array}{l}1957 \\
(10.69)\end{array}$ & $\begin{array}{l}3262 \\
(17.82)\end{array}$ \\
\hline $\begin{array}{l}\text { Munich } \\
(\mathrm{N}=21,363)\end{array}$ & $1,464,301$ & $\begin{array}{l}1209 \\
(5.66)\end{array}$ & $\begin{array}{l}1859 \\
(8.70)\end{array}$ & $\begin{array}{l}3428 \\
(16.04)\end{array}$ & $\begin{array}{l}9712 \\
(45.46)\end{array}$ & $\begin{array}{l}2496 \\
(11.68)\end{array}$ & $\begin{array}{l}1097 \\
(5.14)\end{array}$ & $\begin{array}{l}2230 \\
(10.44)\end{array}$ & $\begin{array}{l}3712 \\
(17.37)\end{array}$ \\
\hline $\begin{array}{l}\text { Cologne } \\
(\mathrm{N}=24,340)\end{array}$ & $1,075,935$ & $\begin{array}{l}1397 \\
(5.74)\end{array}$ & $\begin{array}{l}2247 \\
(9.23)\end{array}$ & $\begin{array}{l}3988 \\
(16.39)\end{array}$ & $\begin{array}{l}10,889 \\
(44.74)\end{array}$ & $\begin{array}{l}2919 \\
(11.99)\end{array}$ & $\begin{array}{l}1357 \\
(5.58)\end{array}$ & $\begin{array}{l}2656 \\
(10.91)\end{array}$ & $\begin{array}{l}4040 \\
(16.60)\end{array}$ \\
\hline $\begin{array}{l}\text { Frankfurt } \\
(\mathrm{N}=27,931)\end{array}$ & 736,414 & $\begin{array}{l}1589 \\
(5.69)\end{array}$ & $\begin{array}{l}2539 \\
(9.09)\end{array}$ & $\begin{array}{l}4645 \\
(16.63)\end{array}$ & $\begin{array}{l}12,542 \\
(44.90)\end{array}$ & $\begin{array}{l}3278 \\
(11.74)\end{array}$ & $\begin{array}{l}1502 \\
(5.38)\end{array}$ & $\begin{array}{l}3073 \\
(11.00)\end{array}$ & $\begin{array}{l}4530 \\
(16.22)\end{array}$ \\
\hline $\begin{array}{l}\text { Stuttgart } \\
(\mathrm{N}=28,799)\end{array}$ & 628,032 & $\begin{array}{l}1705 \\
(5.92)\end{array}$ & $\begin{array}{l}2484 \\
(8.62)\end{array}$ & $\begin{array}{l}4727 \\
(16.42)\end{array}$ & $\begin{array}{l}13,122 \\
(45.56)\end{array}$ & $\begin{array}{l}3439 \\
(11.94)\end{array}$ & $\begin{array}{l}1626 \\
(5.64)\end{array}$ & $\begin{array}{l}3064 \\
(10.64)\end{array}$ & $\begin{array}{l}4657 \\
(16.17)\end{array}$ \\
\hline $\begin{array}{l}\text { Dortmund } \\
(\mathrm{N}=26,804)\end{array}$ & 585,813 & $\begin{array}{l}1593 \\
(5.94)\end{array}$ & $\begin{array}{l}2366 \\
(8.83)\end{array}$ & $\begin{array}{l}4350 \\
(16.23)\end{array}$ & $\begin{array}{l}12,069 \\
(45.03)\end{array}$ & $\begin{array}{l}3382 \\
(12.62)\end{array}$ & $\begin{array}{l}1726 \\
(6.44)\end{array}$ & $\begin{array}{l}3023 \\
(11.28)\end{array}$ & $\begin{array}{l}4198 \\
(15.66)\end{array}$ \\
\hline $\begin{array}{l}\text { Leipzig } \\
(\mathrm{N}=23,256)\end{array}$ & 571,088 & $\begin{array}{l}1392 \\
(5.99)\end{array}$ & $\begin{array}{l}1984 \\
(8.53)\end{array}$ & $\begin{array}{l}3707 \\
(15.94)\end{array}$ & $\begin{array}{l}10,093 \\
(43.40)\end{array}$ & $\begin{array}{l}2884 \\
(12.40)\end{array}$ & $\begin{array}{l}1219 \\
(5.24)\end{array}$ & $\begin{array}{l}2590 \\
(11.14)\end{array}$ & $\begin{array}{l}3977 \\
(17.10)\end{array}$ \\
\hline $\begin{array}{l}\text { Dresden } \\
(\mathrm{N}=23,384)\end{array}$ & 547,172 & $\begin{array}{l}1482 \\
(6.34)\end{array}$ & $\begin{array}{l}1990 \\
(8.51)\end{array}$ & $\begin{array}{l}3540 \\
(15.14)\end{array}$ & $\begin{array}{l}10,651 \\
(45.55)\end{array}$ & $\begin{array}{l}2941 \\
(12.58)\end{array}$ & $\begin{array}{l}1177 \\
(5.03)\end{array}$ & $\begin{array}{l}2601 \\
(11.12)\end{array}$ & $\begin{array}{l}3739 \\
(15.99)\end{array}$ \\
\hline $\begin{array}{l}\text { Hannover } \\
(\mathrm{N}=29,405)\end{array}$ & 532,864 & $\begin{array}{l}1717 \\
(5.84)\end{array}$ & $\begin{array}{l}2719 \\
(9.25)\end{array}$ & $\begin{array}{l}4851 \\
(16.50)\end{array}$ & $\begin{array}{l}12,941 \\
(44.01)\end{array}$ & $\begin{array}{l}3549 \\
(12.07)\end{array}$ & $\begin{array}{l}1687 \\
(5.74)\end{array}$ & $\begin{array}{l}3354 \\
(11.40)\end{array}$ & $\begin{array}{l}4643 \\
(15.79)\end{array}$ \\
\hline $\begin{array}{l}\text { Nuremberg } \\
(\mathrm{N}=27,934)\end{array}$ & 511,628 & $\begin{array}{l}1667 \\
(5.97)\end{array}$ & $\begin{array}{l}2557 \\
(9.15)\end{array}$ & $\begin{array}{l}4535 \\
(16.23)\end{array}$ & $\begin{array}{l}12,658 \\
(45.31)\end{array}$ & $\begin{array}{l}3389 \\
(12.13)\end{array}$ & $\begin{array}{l}1597 \\
(5.72)\end{array}$ & $\begin{array}{l}3145 \\
(11.26)\end{array}$ & $\begin{array}{l}4329 \\
(15.50)\end{array}$ \\
\hline $\begin{array}{l}\text { Kiel } \\
(\mathrm{N}=35,027)\end{array}$ & 247,441 & $\begin{array}{l}2219 \\
(6.33)\end{array}$ & $\begin{array}{l}3302 \\
(9.43)\end{array}$ & $\begin{array}{l}5508 \\
(15.73)\end{array}$ & $\begin{array}{l}15,749 \\
(44.96)\end{array}$ & $\begin{array}{l}4066 \\
(11.61)\end{array}$ & $\begin{array}{l}1908 \\
(5.45)\end{array}$ & $\begin{array}{l}3876 \\
(11.06)\end{array}$ & $\begin{array}{l}5428 \\
(15.50)\end{array}$ \\
\hline $\begin{array}{l}\text { Magdeburg } \\
(\mathrm{N}=25,725)\end{array}$ & 238,136 & $\begin{array}{l}1655 \\
(6.43)\end{array}$ & $\begin{array}{l}1969 \\
(7.66)\end{array}$ & $\begin{array}{l}3523 \\
(13.70)\end{array}$ & $\begin{array}{l}11,758 \\
(45.71)\end{array}$ & $\begin{array}{l}3099 \\
(12.05)\end{array}$ & $\begin{array}{l}1302 \\
(5.06)\end{array}$ & $\begin{array}{l}3141 \\
(12.21)\end{array}$ & $\begin{array}{l}4170 \\
(16.21)\end{array}$ \\
\hline $\begin{array}{l}\text { Freiburg } \\
(\mathrm{N}=39,501)\end{array}$ & 227,590 & $\begin{array}{l}2474 \\
(6.26)\end{array}$ & $\begin{array}{l}3203 \\
(8.11)\end{array}$ & $\begin{array}{l}6534 \\
(16.54)\end{array}$ & $\begin{array}{l}18,103 \\
(45.83)\end{array}$ & $\begin{array}{l}4302 \\
(10.89)\end{array}$ & $\begin{array}{l}2144 \\
(5.43)\end{array}$ & $\begin{array}{l}4772 \\
(12.08)\end{array}$ & $\begin{array}{l}5571 \\
(14.10)\end{array}$ \\
\hline $\begin{array}{l}\text { Rostock } \\
(\mathrm{N}=27,656)\end{array}$ & 207,513 & $\begin{array}{l}1711 \\
(6.19)\end{array}$ & $\begin{array}{l}2231 \\
(8.07)\end{array}$ & $\begin{array}{l}3653 \\
(13.21)\end{array}$ & $\begin{array}{l}12,867 \\
(46.52)\end{array}$ & $\begin{array}{l}3301 \\
(11.94)\end{array}$ & $\begin{array}{l}1460 \\
(5.28)\end{array}$ & $\begin{array}{l}3446 \\
(12.46)\end{array}$ & $\begin{array}{l}4274 \\
(15.46)\end{array}$ \\
\hline $\begin{array}{l}\text { Saarbrucken } \\
(\mathrm{N}=32,503)\end{array}$ & 179,709 & $\begin{array}{l}1898 \\
(5.84)\end{array}$ & $\begin{array}{l}2515 \\
(7.74)\end{array}$ & $\begin{array}{l}4875 \\
(15.00)\end{array}$ & $\begin{array}{l}15,442 \\
(47.51)\end{array}$ & $\begin{array}{l}3734 \\
(11.49)\end{array}$ & $\begin{array}{l}1870 \\
(5.75)\end{array}$ & $\begin{array}{l}4018 \\
(12.36)\end{array}$ & $\begin{array}{l}4646 \\
(14.30)\end{array}$ \\
\hline $\begin{array}{l}\text { Total } \\
(\mathrm{N}=21,701)\end{array}$ & $13,138,904$ & $\begin{array}{l}1272 \\
(5.86)\end{array}$ & $\begin{array}{l}1896 \\
(8.74)\end{array}$ & $\begin{array}{l}3409 \\
(15.71)\end{array}$ & $\begin{array}{l}9759 \\
(44.97)\end{array}$ & $\begin{array}{l}2566 \\
(11.82)\end{array}$ & $\begin{array}{l}1186 \\
(5.46)\end{array}$ & $\begin{array}{l}2392 \\
(11.02)\end{array}$ & $\begin{array}{l}3676 \\
(16.94)\end{array}$ \\
\hline
\end{tabular}

${ }^{\mathrm{a} O v e r a l l ~ s e a r c h ~ v o l u m e / 100,000 ~ i n h a b i t a n t s ~}$

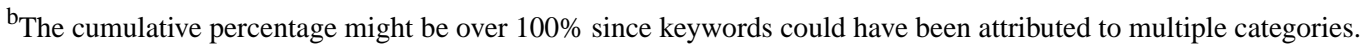

${ }^{\mathrm{c}}$ Number of keywords.

\section{External Factors}

Data from the Climate Data Center [34] (ie, mean monthly temperature in ${ }^{\circ} \mathrm{C}$, mean humidity in $\%$, and mean monthly sunshine duration in hours) as well as atmospheric particulate matter 10 micrometers or less in diameter (PM10) data from federal states and federal government networks (Messnetze der Bundesländer sowie des Bundes) [37] were used to determine 
whether there were correlations with the number of search queries within each city. In addition, the correlation between searches and the supply of dermatologists and GPs [32], as well as the respective inhabitants' demographics (ie, mean age, proportion of female inhabitants, or proportion of nonnative German inhabitants) [39-41], was examined.

\section{Statistical Analysis}

Descriptive data were generated for all categorized keywords. To determine differences in search volume per 100,000 inhabitants within cities and regions, one-way analysis of variance (ANOVA) was used. Pearson's correlation coefficient was used to assess the relationship between the number of search queries and the abovementioned external factors. Additionally, a linear regression model was generated to further assess the relationship between search queries and environmental factors. Forward selection was used to generate the best-fit model. Standardized regression coefficients (beta) and 95\% CIs were estimated. Stratified analyses by region were also performed. IBM SPSS Statistics for Windows, version 25.0 (IBM Corp) was used for the statistical and spatial analyses. Geodata from the German Federal Agency for Cartography and Geodesy [42] were used to determine administrative boundaries using a geographic information system, QGIS, version 2.14.22 (QGIS Development Team).

\section{Results}

\section{Overview}

In total, 1177 keywords related to the German lay word for pruritus were identified in all 16 German cities. Of these, 1150 were considered for further analyses, resulting in a search volume of 2,851,290 queries. Most of the keywords were assigned to the localization category (499/1150, 43.39\%), whereas the smallest number of keywords were categorized as causes $(94 / 1150,8.17 \%)$ (see Figure 2). The most-searched-for keywords were "pruritus" $(\mathrm{n}=115,680)$, "anal pruritus" $(\mathrm{n}=102,390)$, "pruritus on the whole body" $(\mathrm{n}=56,660)$, and "itchy skin” ( $n=53,480)$ (see Multimedia Appendix 1).

Figure 2. Content categorization of search terms identified by Google AdWords Keyword Planner.

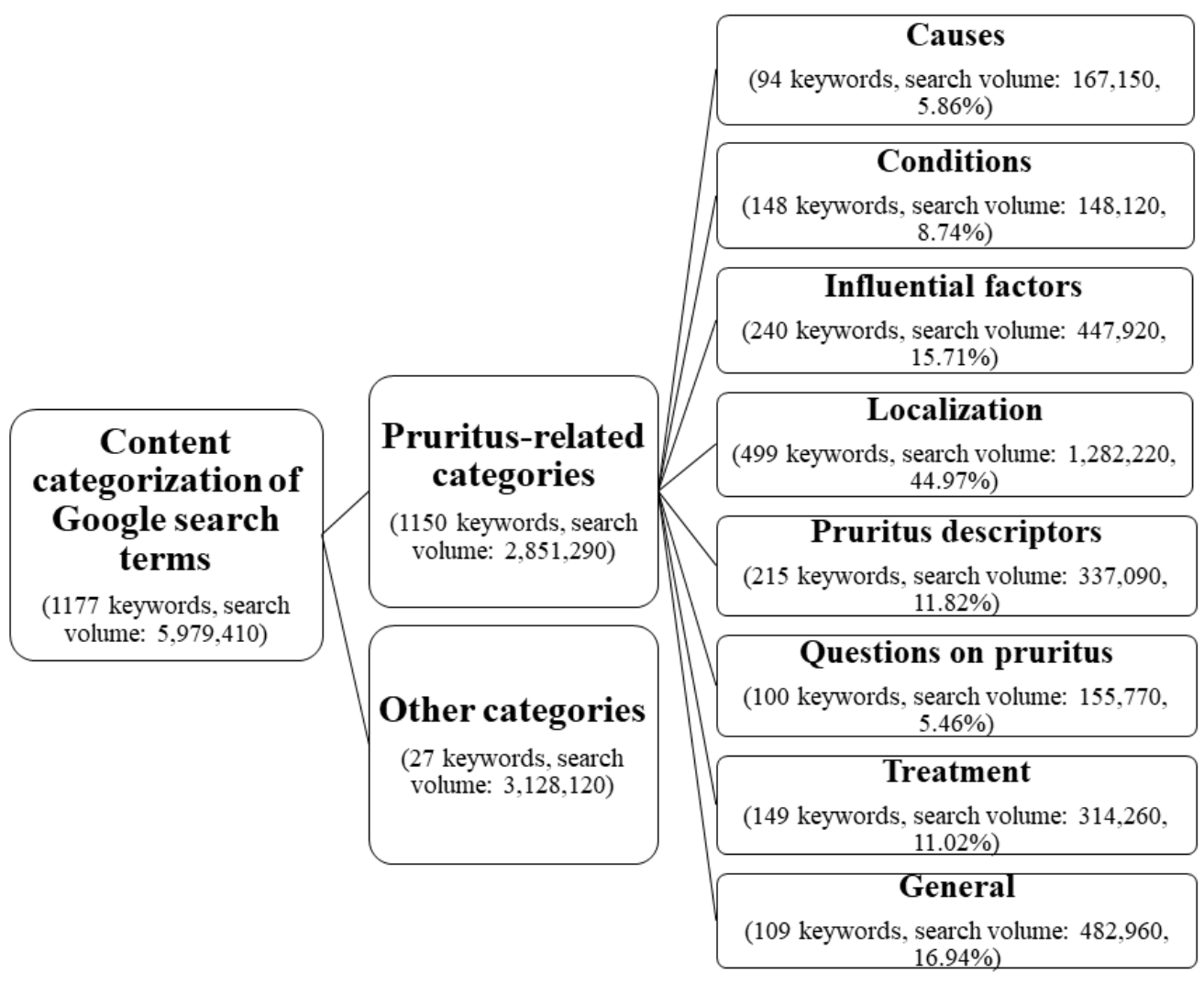

\section{Comparison of 16 Cities Across Germany}

As expected, the greatest number of absolute searches for pruritus-related keywords occurred in the most populated German cities: Berlin $(n=487,650)$, Hamburg $(n=331,360)$, and Munich $(n=312,820)$. However, when adjusting the search volume by the number of inhabitants, Freiburg and Kiel had the highest number per 100,000 inhabitants, with 39,501 and 35,027 search queries, respectively (see Figure 1). The analyses showed that Berlin had a significantly lower number of search queries per 100,000 inhabitants $(n=13,641)$ than all other cities except for Hamburg ( $\mathrm{n}=18,303, P=.99)$ and Munich $(\mathrm{n}=21,363$, $P=.05)$. Overall, in Eastern Germany, the number of search queries $(86,006$ searches/100,000 inhabitants) was lower compared to Northern Germany (110,391 searches/100,000 inhabitants, $\quad P<.001), \quad$ Southern Germany $\quad(117,597$ searches/100,000 inhabitants, $P<.001)$, and Western Germany $(111,578$ searches $/ 100,000$ inhabitants, $P<.001)$.

About $43.4 \%-47.5 \%$ of all queries were related to the body parts affected by pruritus, meaning that localization was the category with the highest relative number of searches: 9759 searches per 
100,000 inhabitants. Especially in Berlin and Munich, a high proportion of people (844/4103 [20.57\%] searches/100,000 inhabitants and 1311/6519 [20.11\%] searches/100,000 inhabitants, respectively) searched for pruritus in the genital or anal areas, while, overall, approximately $11.55 \%$ of localization-related keywords focused on these areas. A total of 2566 searches per 100,000 inhabitants included more specific pruritus descriptors, such as "constant" (457/2566 [17.81\%] searches $/ 100,000$ inhabitants). In Berlin, the number of searches per 100,000 inhabitants for keywords including information on pruritus descriptors only was 1537 , while more than 4000 searches were registered in Kiel and Freiburg. In general, people searched more frequently for information on chronic pruritus (80/2566 [3.12\%] searches/100,000 inhabitants) compared to acute pruritus (17/2566 [0.66\%] searches/100,000 inhabitants). The most-searched influential factor was "liver" (515/3409 [15.12\%] searches/100,000 inhabitants), followed by "stress" (365/3409 [10.72\%] searches/100,000 inhabitants) and "allergy" (354/3409 [10.39\%] searches per 100,000 inhabitants). Of all categories, questions on pruritus was the category with the fewest number of searches: 1186 searches per 100,000 inhabitants. The proportion ranged from $5.0 \%$ to $6.4 \%$ among the cities, with the lowest proportion recorded in Dresden and the highest in Dortmund (see Table 1 and 2).

The vast majority of categories were negatively correlated with each other. The categories conditions, influential factors, and general showed a negative correlation with all other categories. Compared to that, a positive correlation was detected between the categories questions on pruritus and causes $(\mathrm{r}=.12, P<.001)$ as well as treatment $(\mathrm{r}=.34, P<.001)$.

\section{Time Course of Search Behavior}

The average monthly number of searches was 452 per 100,000 inhabitants, with the greatest number occurring in Freiburg $(\mathrm{n}=823)$ and the smallest in Berlin $(\mathrm{n}=284)$. While the monthly number of searches per capita remained relatively stable in Berlin (range 239-370: 131) and Hamburg (range 316-482: 166), high seasonal ranges were observed in Kiel (range 566-946: 390) and Freiburg (range 620-1019: 399). Interestingly, a major decrease in search queries was observed in Saarbrucken from October 2015 to April 2016, whereas it was increased in all other cities in Western Germany. Except for Frankfurt, Dortmund, Freiburg, and Saarbrucken, the vast majority of cities had the highest relative number of search queries during the winter (ie, December to February). Across the four aberrant cities, the greatest numbers of searches were observed in March 2016 in Frankfurt ( $\mathrm{n}=754)$, March 2016 in Dortmund ( $\mathrm{n}=743)$, July 2015 in Freiburg $(n=1019)$, and October 2015 in Saarbrucken $(n=913)$. Overall, the highest number of relative searches occurred in January $2016(n=562)$ and the lowest occurred in August $2014(\mathrm{n}=378)$ (see Figure 3). 
Table 2. The five most-searched-for terms within each category across all examined cities, expressed as search queries per 100,000 inhabitants.

\begin{tabular}{|c|c|}
\hline Category and search terms & $\mathrm{n}^{\mathrm{a}}(\%)$ \\
\hline \multicolumn{2}{|l|}{ Conditions ( $\mathrm{N}=1896)$} \\
\hline Most common: During night-time & $666(35.12)$ \\
\hline Second-most common: During the evening & $499(26.30)$ \\
\hline Third-most common: During pregnancy & $217(11.46)$ \\
\hline Fourth-most common: Heat-induced & $94(4.97)$ \\
\hline Fifth-most common: During winter & $87(4.60)$ \\
\hline \multicolumn{2}{|l|}{ Influencing factors $(\mathrm{N}=3409)$} \\
\hline Most common: Liver & $515(15.12)$ \\
\hline Second-most common: Stress & $365(10.72)$ \\
\hline Third-most common: Allergies & $354(10.39)$ \\
\hline Fourth-most common: Diabetes & $331(9.70)$ \\
\hline Fifth-most common: Dry skin & $319(9.34)$ \\
\hline \multicolumn{2}{|l|}{ Localization $(\mathrm{N}=9759)$} \\
\hline Most common: Whole body & $3375(34.59)$ \\
\hline Second-most common: Legs & $1516(15.53)$ \\
\hline Third-most common: Anal or genital area & $1127(11.55)$ \\
\hline Fourth-most common: Hands & $877(8.98)$ \\
\hline Fifth-most common: Head & $791(8.11)$ \\
\hline \multicolumn{2}{|l|}{ Pruritus descriptors $(\mathrm{N}=2566)$} \\
\hline Most common: Strong & $812(31.65)$ \\
\hline Second-most common: Constant & $457(17.81)$ \\
\hline Third-most common: Sudden & $392(15.26)$ \\
\hline Fourth-most common: Extreme & $286(11.16)$ \\
\hline Fifth-most common: Burning & $142(5.54)$ \\
\hline \multicolumn{2}{|l|}{ Questions on pruritus (N=1186) } \\
\hline Most common: What helps against pruritus? & $120(10.12)$ \\
\hline Second-most common: What helps against pruritus on the whole body? & $45(3.79)$ \\
\hline Third-most common: Why does the skin develop pruritus? & $45(3.79)$ \\
\hline Fourth-most common: What helps against itchy skin? & $41(3.45)$ \\
\hline Fifth-most common: How does pruritus occur? & $38(3.20)$ \\
\hline \multicolumn{2}{|l|}{ Treatment $(\mathrm{N}=\mathbf{2 3 9 2})$} \\
\hline Most common: General & $1205(50.36)$ \\
\hline Second-most common: Ointment & $290(12.14)$ \\
\hline Third-most common: Cream & $271(11.31)$ \\
\hline Fourth-most common: Drugs & $204(8.54)$ \\
\hline Fifth-most common: Home remedies & $179(7.48)$ \\
\hline
\end{tabular}

${ }^{\mathrm{a}}$ Number of searches/100,000 inhabitants. 
Figure 3. Trends in Google search volume per 100,000 inhabitants for pruritus-related keywords in 16 German cities from August 2014 to July 2018.
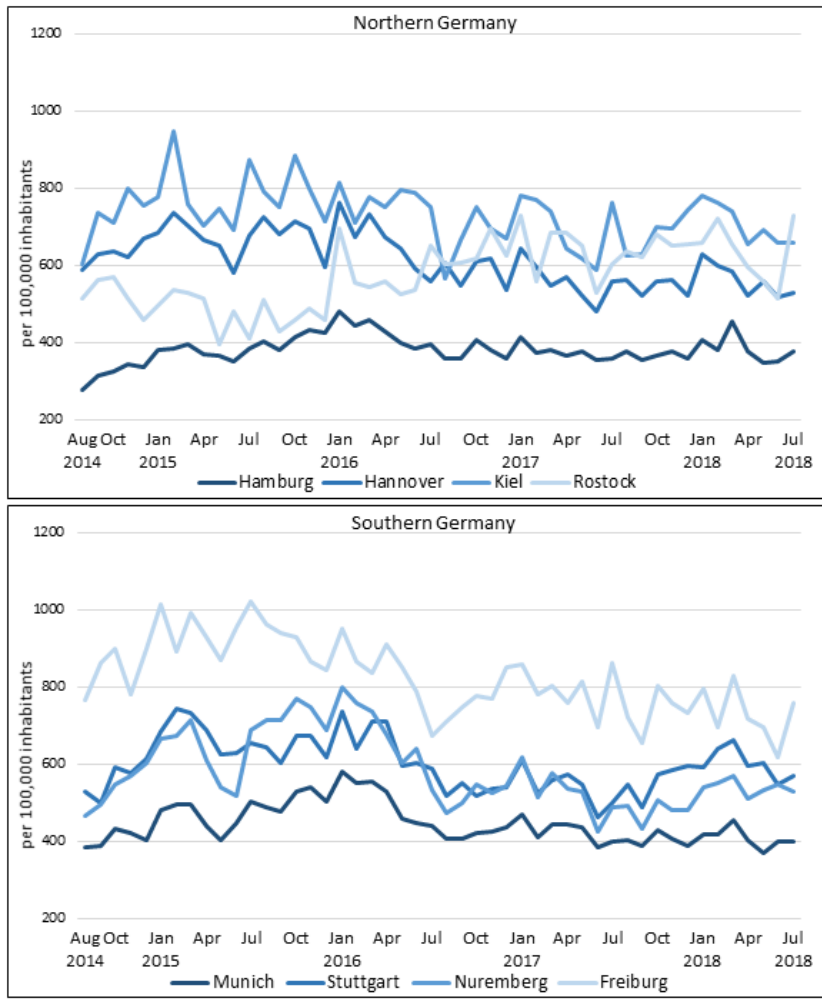

\section{Supply of Dermatologists and General Practitioners}

A high correlation between the number of search queries per 100,000 inhabitants and the supply of dermatologists $(r=.56$, $P=.02$ ) was identified (see Figure 1). This correlation was stronger than the correlation with the supply of GPs ( $\mathrm{r}=.34$, $P=.19$ ). When search terms that did not explicitly include pruritus (eg, "psoriasis" or "atopic eczema") were also included in the analyses, the correlation was $.51(P=.05)$ for the supply of dermatologists and $.50(P=.05)$ for that of GPs.

\section{Inhabitants' Demographics}

The number of search queries per 100,000 inhabitants was negatively correlated with the respective inhabitants' mean age $(\mathrm{r}=-.12, P=.67)$ and the proportion of nonnative Germans (r=-.05, $P=.85)$. In contrast, the proportion of female searchers showed a positive association $(\mathrm{r}=.33, P=.21)$. However, none of these correlations were significant.

\section{Environmental Factors}

Overall, a negative correlation was observed between searches and temperature $(\mathrm{r}=-.14, P<.001)$. This correlation was especially high in Berlin and Leipzig ( $\mathrm{r}=-.59, P<.001$ and $\mathrm{r}=-.52$, $P<.001$, respectively). In contrast to temperature, monthly

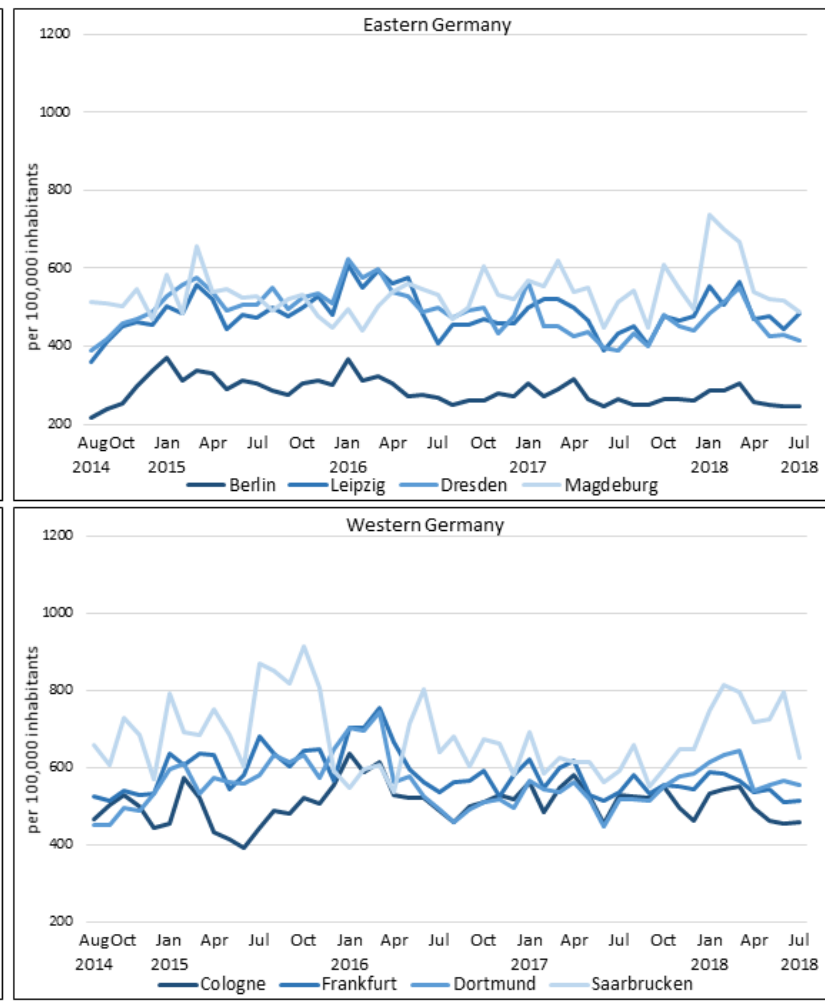

relative humidity was positively correlated with the searches, indicating that the number of search queries increased with higher humidity $(\mathrm{r}=.15, \quad P<.001)$. The most significant correlations with humidity were detected in Berlin $(\mathrm{r}=.32$, $P=.03$ ), Cologne (r=.33, $P=.02)$, and Kiel ( $\mathrm{r}=.35, P=.02$ ) (see Table 3).

Overall, the monthly mean daily temperature had the greatest effect on the number of search queries per 100,000 inhabitants, with lower temperatures resulting in a higher number of search queries (beta $-7.94,95 \%$ CI -10.74 to -5.15 ). This effect was particularly high in Eastern Germany (beta -11.74 , 95\% CI -15.94 to -7.54 ) and Western Germany (beta $-9.23,95 \%$ CI -12.5 to 5.92). The level of PM10 was also associated with a highly negative effect (beta $-5.13,95 \%$ CI -7.04 to -3.22 ), whereas relative humidity (beta $4.72,95 \%$ CI 2.70 to 6.75 ) and the duration of sunshine (beta $0.66,95 \%$ CI 0.36 to 0.97 ) showed a positive effect. However, when analyzing these influences with respect to different regions, PM10 was found to exert a highly positive effect in Northern Germany (beta $6.42,95 \%$ CI 2.41 to 10.43 ). In contrast, a negative effect was observed in all the other regions: Eastern Germany (beta $-7.33,95 \%$ CI -10.42 to -4.25 ), Southern Germany (beta $-3.50,95 \%$ CI -6.65 to -0.35 ), and Western Germany (beta $-8.14,95 \%$ CI -10.75 to -5.53 ) (see Table 4). 
Table 3. Correlation between the number of search queries and selected environmental factors across 16 German cities from August 2014 to July 2018.

\begin{tabular}{|c|c|c|c|c|c|c|c|c|c|c|c|c|}
\hline \multirow[t]{2}{*}{ Cities } & \multicolumn{3}{|c|}{ Monthly temperature $\left({ }^{\circ} \mathrm{C}\right)$} & \multicolumn{3}{|c|}{ Monthly humidity (\%) } & \multicolumn{3}{|c|}{ Monthly sunshine duration (hours) } & \multicolumn{3}{|c|}{ Monthly PM10 ${ }^{\mathrm{a}}\left(\mu \mathrm{g} / \mathrm{m}^{3}\right)$} \\
\hline & Mean (SD) & $\mathrm{r}^{\mathrm{b}}$ & $P$ & Mean (SD) & $\mathrm{r}$ & $\mathrm{P}$ & Mean (SD) & $\mathrm{r}$ & $\mathrm{P}$ & Mean (SD) & $\mathrm{r}$ & $\mathrm{P}$ \\
\hline Berlin & $11.0(7.0)$ & -.59 & $<.001$ & $73.0(9.9)$ & .32 & .03 & $140.1(81.0)$ & -.41 & .003 & $23.9(5.9)$ & .28 & .06 \\
\hline Hamburg & $10.1(9.2)$ & -.44 & .002 & $80.4(7.1)$ & .18 & .22 & $131.5(76.8)$ & -.33 & .02 & $20.0(4.5)$ & .11 & .48 \\
\hline Munich & $10.7(7.1)$ & -.33 & .02 & $72.8(7.5)$ & .07 & .63 & $146.9(74.0)$ & -.20 & .18 & $20.5(6.8)$ & .27 & .06 \\
\hline Cologne & $12.0(6.1)$ & -.47 & .001 & $74.9(8.3)$ & .33 & .02 & $125.2(66.2)$ & -.41 & .004 & $23.3(4.1)$ & .13 & .37 \\
\hline Frankfurt & $11.4(6.8)$ & -.36 & .01 & $74.2(10.1)$ & .04 & .80 & $133.3(77.6)$ & -.18 & .24 & $21.3(5.1)$ & .06 & .70 \\
\hline Stuttgart & $11.3(6.8)$ & -.41 & .003 & $72.6(8.3)$ & .01 & .97 & $148.0(75.3)$ & -.29 & .046 & $19.9(6.7)$ & .12 & .40 \\
\hline Dortmund & $11.0(6.8)$ & -.47 & .001 & $77.1(6.4)$ & .10 & .50 & $128.6(63.2)$ & -.28 & .06 & $23.0(4.9)$ & .004 & .98 \\
\hline Leipzig & $10.6(6.8)$ & -.52 & $<.001$ & $75.9(8.0)$ & .09 & .56 & $137.8(72.9)$ & -.29 & .049 & $21.0(5.8)$ & .38 & .007 \\
\hline Dresden & $11.1(6.9)$ & -.48 & .001 & $73.2(7.8)$ & .23 & .12 & $136.1(69.8)$ & -.24 & .10 & $21.1(5.7)$ & .50 & $<.001$ \\
\hline Hannover & $10.5(6.2)$ & -.38 & .008 & $78.4(7.5)$ & .21 & .15 & $127.2(72.3)$ & -.27 & .07 & $19.1(4.2)$ & .35 & .01 \\
\hline Nuremberg & $10.4(7.0)$ & -.31 & .03 & 75.9 (9.6) & .12 & .42 & $144.1(81.1)$ & -.32 & .03 & $24.0(8.4)$ & .33 & .02 \\
\hline Kiel & $10.0(5.9)$ & -.38 & .009 & 82.5 (5.7) & .35 & .02 & $135.0(90.7)$ & -.37 & .009 & $21.9(5.8)$ & .54 & $<.001$ \\
\hline Magdeburg & $10.8(6.8)$ & -.33 & .02 & $75.9(8.7)$ & .11 & .45 & $142.5(78.4)$ & -.14 & .36 & $20.3(4.8)$ & .04 & .80 \\
\hline Freiburg & $11.4(6.7)$ & -.19 & .20 & 75.9 (7.3) & .06 & .67 & $149.9(76.3)$ & -.14 & .36 & $16.0(4.8)$ & .30 & .04 \\
\hline Rostock & $10.2(6.1)$ & -.22 & .13 & $79.0(5.2)$ & .22 & .13 & $150.8(90.6)$ & -.18 & .21 & $19.8(5.1)$ & .04 & .79 \\
\hline Saarbrucken & $11.2(6.5)$ & .08 & .57 & $78.2(9.3)$ & -.22 & .14 & $134.4(80.7)$ & .04 & .80 & $18.0(4.2)$ & -.05 & .76 \\
\hline All cities & $10.9(6.5)$ & -.14 & $<.001$ & $76.2(8.4)$ & .15 & $<.001$ & $138.2(76.7)$ & -.09 & .01 & $20.8(5.9)$ & -.08 & .04 \\
\hline
\end{tabular}

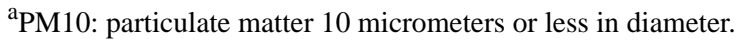

${ }^{b}$ Pearson's correlation coefficient (r) was used to assess the correlation between the number of search queries and selected environmental factors within the city.

Table 4. Results of the linear regression using forward selection to assess the relationship between environmental factors and number of search queries per 100,000 inhabitants.

\begin{tabular}{|c|c|c|c|c|c|}
\hline \multirow[t]{2}{*}{ Covariates } & \multicolumn{5}{|c|}{ Linear regression results for each German region, $\mathrm{OR}^{\mathrm{a}}(95 \% \mathrm{CI})$} \\
\hline & Overall & Northern Germany & Eastern Germany & Southern Germany & Western Germany \\
\hline \multirow[t]{2}{*}{$\mathrm{PM} 10^{\mathrm{b}}$} & -5.13 & 6.42 & -7.33 & -3.50 & -8.14 \\
\hline & $(-7.04$ to -3.22$)$ & $(2.41$ to 10.43$)$ & $(-10.42$ to -4.25$)$ & $(-6.65$ to -0.35$)$ & $(-10.75$ to -5.54$)$ \\
\hline \multirow[t]{2}{*}{ Temperature } & -7.94 & $N / A^{c}$ & -11.74 & N/A & -9.23 \\
\hline & $(-10.74$ to -5.15$)$ & & $(-15.94$ to -7.54$)$ & & $(-12.5$ to 5.92$)$ \\
\hline \multirow[t]{2}{*}{ Sunshine duration } & 0.66 & N/A & 1.25 & N/A & 0.40 \\
\hline & $(0.36$ to 0.97$)$ & & $(0.71$ to 1.79$)$ & & (0.13 to 0.67$)$ \\
\hline \multirow[t]{2}{*}{ Humidity } & 4.72 & N/A & 7.07 & 3.58 & N/A \\
\hline & $(2.70$ to 6.75$)$ & & (3.41 to 10.72 ) & $(0.80$ to 6.36$)$ & \\
\hline
\end{tabular}

${ }^{\mathrm{a}} \mathrm{OR}$ : odds ratio.

${ }^{\mathrm{b}} \mathrm{PM} 10$ : particulate matter 10 micrometers or less in diameter.

${ }^{\mathrm{c}}$ Not applicable; since a linear regression using forward selection was performed, some of the variables were not significant within each region.

\section{Discussion}

\section{Principal Findings}

From August 2014 to July 2018, 2,851,290 Google searches were performed for pruritus in the 16 examined German cities. Overall, the most common search terms were "pruritus," "anal pruritus," "pruritus on the whole body," and "itchy skin." The analyses showed that Berlin, Hamburg, and Munich, Germany's three most-populated cities, had a comprehensively lower number of search queries per 100,000 inhabitants compared with smaller cities like Saarbrucken, Kiel, and Freiburg. In almost all cities, the highest number of searches were observed in the winter, with most occurring in January 2016 and the least number of searches occurring in August 2014. 
There is some evidence that Google search analyses are an effective and inexpensive tool for assessing disease trends, such as seasonal variation in multiple medical fields [27,29,43]. Previous studies using Google Trends data demonstrated correlations with various sources of data, such as coronary heart disease epidemiology [44], cancer incidence and mortality rates [29], and cases of Ebola virus disease [45]. Each of the studies showed a positive correlation, which suggested that this is an alternative solution for disease surveillance [43]. This study investigated a possible correlation between search volume and the supply of physicians. The results indicated that the number of search queries showed a higher correlation with the supply of dermatologists $(r=.56)$ than with the supply of GPs $(r=.34)$. This was also the case when considering search terms, such as "psoriasis" or "atopic eczema." One explanation for this discrepancy could be that, comparable to the diagnosis of xerosis [36], people consulting a dermatologist might receive a specific diagnosis for their pruritus and, therefore, may have performed explicit searches for pruritus. However, people seeing GPs might receive other less-specific diagnoses. Otherwise, this could indicate that, in spite of a high supply of physicians, there is still a definite need for medical care.

This study also revealed that the number of searches was correlated with climate. Interestingly, the effect of weather data differed within the regions. For example, in Northern Germany, only PM10 was found to have a significant effect on search behavior, while in Eastern Germany, all environmental factors examined were significant. Additionally, PM10 had a positive effect on the number of search queries in Northern Germany, which was contrary to all other regions. Although this study points to a negative effect from PM10, a positive effect, as it was observed in Northern Germany, is feasible since previous studies reported an association with pruritus or eczema [46]. Humidity and duration of sunshine were found to have a consistent positive effect across all regions. Temperature, in particular, was found to have a great effect on the number of search queries. It was found that a $1^{\circ} \mathrm{C}$ decrease in average monthly temperature correlated with around 8 more search queries per 100,000 inhabitants, with a greater effect observed in Eastern and Western Germany. Previous studies already reported that temperature influences the occurrence of pruritus $[33,35]$; for example, pruritus caused by xerosis is more common in colder months $[36,47]$. Similar to other German studies $[30,31]$, we found an overall negative correlation between temperature and search volume across all cities during the entire study period $(\mathrm{r}=-\mathrm{.14})$. A study in the United States and the United Kingdom, however, reported contrary results $\left(r_{\mathrm{s}}=.42\right.$ and $r_{s}=.27$, respectively) [48]. Since no evidence was found that the United States or the United Kingdom generally have a warmer climate, search behavior has to be influenced by several other factors, for example, populations' demographics, health campaigns, or medial visibility of diseases [23,49,50]. Despite an overall negative correlation with temperature, there were a few cities with a strikingly high number of searches in warmer months: Kiel, Freiburg, and Saarbrucken in July 2015. However, no considerable search-related differences according to temperature, humidity, PM10, or cumulative sunshine duration were found in comparison with other years. Thus, it confirms that there must be additional variables (eg, prevalence of allergies and pollen season) that influence search behaviors. This seems to be supported by the fact that a strong decline in search volume was observed in Saarbrucken from October 2015 to April 2016, while there were increases in Cologne, Dortmund, and Frankfurt, even though no significant differences in environmental factors were identified.

Besides examining disease trends, Google data can also be used for gaining insights into people's health information-seeking behaviors [23,30,31]. Previous studies examining Google search volumes of pruritus-related keywords across Germany showed that the vast majority of searches $(72.0 \%-72.6 \%)$ focused on influential factors [30,31], whereas most of the searches we found were related to localization (43.4\%-47.5\%) and only a small proportion were focused on influential factors (13.2\%-16.6\%). These differences might have occurred because this study only considered urban populations and search terms that explicitly included words or phrases related to pruritus, while other studies considered a larger population and additional keywords such as "psoriasis" and "atopic eczema." Apart from this discrepancy, our results are mainly consistent with others in the literature. A differentiated consideration of the cities further enables the identification of general differences in medical needs or for a specific condition. When setting the search volume in relation to the respective inhabitants, we found that smaller cities were more likely to have a higher number of search queries. The highest relative search volume was observed in Freiburg, which might be somewhat influenced by the highest proportion of female inhabitants and lowest mean age in comparison to all other cities $[39,41]$. The results also indicated that people living in Berlin searched less frequently for information, and those who used Google were more likely to use unspecific keywords, which is expressed by the highest proportion of general keywords. At the same time, people living in Berlin or Munich seemed to have an especially high interest in anal pruritus, as $20.57 \%$ and $20.11 \%$, respectively, of all localization-related searches focused on anal pruritus (overall $11.55 \%$ ). If prevention campaigns could be adapted to regional differences, they might help to better address people's therapeutic needs.

\section{Limitations}

There are some limitations to this study that should be discussed. Google analyses are restricted to people who have access to the Internet and use Google as a search engine. In general, younger people use the Internet more frequently [24]. Since the Google AdWords Keyword Planner does not provide information on users' general demographics, no statement about the examined population can be made. Although no clear correlation between the inhabitants' mean age, percentage of female inhabitants, or percentage of nonnative Germans was found in this study, the study results might be somewhat influenced by them. On the one hand, this might have led to an underestimation of the pruritus burden, which is actually more prevalent among older people [9]. On the other hand, differences in the number of searches could result from the age distribution of Google users across the cities. Moreover, the search volume could have been influenced by different proportions of nonnative German speakers within the cities, as the study setting was limited to 
people whose language of preference was German, with respect to Google use and German search terms. A further limitation was that Google provides automatic completion of search terms, which might bias people's search behavior.

\section{Conclusions}

By taking into account the study objective and results, analyses of Google data are extremely useful for medical care since the public's search behavior, including interest and frequency, could be investigated. Moreover, the study found that, for example, the number of search queries was negatively correlated with temperature and PM10, whereas it was positively correlated with humidity and sunshine duration. Considering this information, the analyses seemed to be valuable in forecasting higher public interest and need when weather is changing. In addition to this study, future studies could focus on age- or sex-specific aspects of dermatologic conditions to better target population-specific health care needs by implementing specifically adapted public health campaigns.

\section{Conflicts of Interest}

None declared.

\section{Multimedia Appendix 1}

List of keywords and number of times searched.

[PDF File (Adobe PDF File), 45KB-Multimedia Appendix 1]

\section{References}

1. Weisshaar E. Epidemiology of itch. Curr Probl Dermatol 2016;50:5-10. [doi: 10.1159/000446010] [Medline: 27578064]

2. Schut C, Dalgard FJ, Halvorsen JA, Gieler U, Lien L, Aragones LT, et al. Occurrence, chronicity and intensity of itch in a clinical consecutive sample of patients with skin diseases: A multi-centre study in 13 European countries. Acta Derm Venereol 2019 Feb 01;99(2):146-151 [FREE Full text] [doi: 10.2340/00015555-3040] [Medline: 30226526]

3. Stamm LV, Strowd LC. Ignoring the "itch": The global health problem of scabies. Am J Trop Med Hyg 2017 Dec;97(6):1647-1649 [FREE Full text] [doi: 10.4269/ajtmh.17-0242] [Medline: 29016295]

4. Dawn A, Papoiu AD, Chan YH, Rapp SR, Rassette N, Yosipovitch G. Itch characteristics in atopic dermatitis: Results of a Web-based questionnaire. Br J Dermatol 2009 Mar;160(3):642-644. [doi: 10.1111/j.1365-2133.2008.08941.x] [Medline: $\underline{19067703}$ ]

5. Kopyciok ME, Ständer HF, Osada N, Steinke S, Ständer S. Prevalence and characteristics of pruritus: A one-week cross-sectional study in a German dermatology practice. Acta Derm Venereol 2016 Jan;96(1):50-55 [FREE Full text] [doi: 10.2340/00015555-2166] [Medline: 26067841]

6. Yosipovitch G, Goon A, Wee J, Chan YH, Goh CL. The prevalence and clinical characteristics of pruritus among patients with extensive psoriasis. Br J Dermatol 2000 Nov;143(5):969-973. [Medline: 11069504]

7. Matterne U, Apfelbacher CJ, Loerbroks A, Schwarzer T, Büttner M, Ofenloch R, et al. Prevalence, correlates and characteristics of chronic pruritus: A population-based cross-sectional study. Acta Derm Venereol 2011 Oct;91(6):674-679 [FREE Full text] [doi: 10.2340/00015555-1159] [Medline: 21879245]

8. Matterne U, Apfelbacher CJ, Vogelgsang L, Loerbroks A, Weisshaar E. Incidence and determinants of chronic pruritus: A population-based cohort study. Acta Derm Venereol 2013 Sep 04;93(5):532-537 [FREE Full text] [doi: 10.2340/00015555-1572] [Medline: 23450324]

9. Ständer S, Schäfer I, Phan NQ, Blome C, Herberger K, Heigel H, et al. Prevalence of chronic pruritus in Germany: Results of a cross-sectional study in a sample working population of 11,730. Dermatology 2010;221(3):229-235. [doi: 10.1159/000319862] [Medline: 20924157]

10. Marron SE, Tomas-Aragones L, Boira S, Campos-Rodenas R. Quality of life, emotional well-being and family repercussions in dermatological patients experiencing chronic itching: A pilot study. Acta Derm Venereol 2016 Mar;96(3):331-335 [FREE Full text] [doi: 10.2340/00015555-2263] [Medline: 26524077]

11. Pereira MP, Ständer S. Assessment of severity and burden of pruritus. Allergol Int 2017 Jan;66(1):3-7 [FREE Full text] [doi: 10.1016/j.alit.2016.08.009] [Medline: 27634668]

12. Ständer S, Legat F. Pruritus: Future research is to scratch before it starts itching [Article in German]. Hautarzt 2018 Aug;69(8):618-619. [doi: 10.1007/s00105-018-4225-3] [Medline: $\underline{30083775]}$

13. Halvorsen JA, Dalgard F, Thoresen M, Bjertness E, Lien L. Itch and pain in adolescents are associated with suicidal ideation: A population-based cross-sectional study. Acta Derm Venereol 2012 Sep;92(5):543-546 [FREE Full text] [doi: 10.2340/00015555-1251] [Medline: 22068440]

14. Balieva F, Kupfer J, Lien L, Gieler U, Finlay AY, Tomás-Aragonés L, et al. The burden of common skin diseases assessed with the EQ5D ${ }^{\mathrm{TM}}$ : A European multicentre study in 13 countries. Br J Dermatol 2017 May;176(5):1170-1178. [doi: 10.1111/bjd.15280] [Medline: 28032340]

15. Weisshaar E, Szepietowski JC, Darsow U, Misery L, Wallengren J, Mettang T, et al. European guideline on chronic pruritus. Acta Derm Venereol 2012 Sep;92(5):563-581 [FREE Full text] [doi: 10.2340/00015555-1400] [Medline: 22790094] 
16. Ständer S, Weisshaar E, Mettang T, Szepietowski JC, Carstens E, Ikoma A, et al. Clinical classification of itch: A position paper of the International Forum for the Study of Itch. Acta Derm Venereol 2007;87(4):291-294 [FREE Full text] [doi: 10.2340/00015555-0305] [Medline: 17598029 ]

17. Steinke S, Bruland P, Blome C, Osada N, Dugas M, Fritz F, et al. Chronic pruritus: Evaluation of patient needs and treatment goals with a special regard to differences according to pruritus classification and sex. Br J Dermatol 2017 Feb;176(2):363-370. [doi: 10.1111/bjd.14910] [Medline: 27479717]

18. Dalgard F, Holm J, Svensson A, Kumar B, Sundby J. Self-reported skin morbidity and ethnicity: A population-based study in a western community. BMC Dermatol 2007 Jun 29;7:4 [FREE Full text] [doi: 10.1186/1471-5945-7-4] [Medline: $\underline{17603893]}$

19. Ständer S, Blome C, Anastasiadou Z, Zeidler C, Jung KA, Tsianakas A, et al. Dynamic pruritus score: Evaluation of the validity and reliability of a new instrument to assess the course of pruritus. Acta Derm Venereol 2017 Feb 08;97(2):230-234 [FREE Full text] [doi: 10.2340/00015555-2494] [Medline: 27349416]

20. Augustin M, Radtke MA, Zschocke I, Blome C, Behechtnejad J, Schäfer I, et al. The patient benefit index: A novel approach in patient-defined outcomes measurement for skin diseases. Arch Dermatol Res 2009 Sep;301(8):561-571. [doi: 10.1007/s00403-009-0928-8] [Medline: 19326133]

21. Blome C, Gosau R, Radtke MA, Reich K, Rustenbach SJ, Spehr C, et al. Patient-relevant treatment goals in psoriasis. Arch Dermatol Res 2016 Mar;308(2):69-78. [doi: 10.1007/s00403-015-1613-8] [Medline: 26688112]

22. Amante DJ, Hogan TP, Pagoto SL, English TM, Lapane KL. Access to care and use of the Internet to search for health information: Results from the US National Health Interview Survey. J Med Internet Res 2015 Apr 29;17(4):e106 [FREE Full text] [doi: 10.2196/jmir.4126] [Medline: 25925943]

23. Seidl S, Schuster B, Rüth M, Biedermann T, Zink A. What do Germans want to know about skin cancer? A nationwide Google search analysis from 2013 to 2017. J Med Internet Res 2018 Dec 02;20(5):e10327 [FREE Full text] [doi: 10.2196/10327] [Medline: 29698213]

24. Koch W, Frees B. Media Perspektiven. 2017 Sep. ARD/ZDF-Onlinestudie: Neun von zehn Deutschen online URL: $\underline{\text { http:/ }}$ /www.ard-zdf-onlinestudie.de/files/2017/Artikel/917_Koch_Frees.pdf [accessed 2018-07-05]

25. Directorate-General for Communications Networks, Content and Technology (European Commission). European Citizens' Digital Health Literacy. Brussels, Belgium: European Union; 2015 Jan 22. URL: https://publications.europa.eu/en/ publication-detail/-/publication/fd42f9e7-937c-41f3-bf03-4221b2db712b [accessed 2018-08-02]

26. Statista. Statistiken zu suchmaschinen (Search engine statistics) URL: https://de.statista.com/themen/111/suchmaschinen/ [accessed 2018-07-06]

27. Mavragani A, Ochoa G, Tsagarakis KP. Assessing the methods, tools, and statistical approaches in Google Trends research: Systematic review. J Med Internet Res 2018 Dec 06;20(11):e270 [FREE Full text] [doi: 10.2196/jmir.9366] [Medline: $\underline{30401664]}$

28. Ginsberg J, Mohebbi MH, Patel RS, Brammer L, Smolinski MS, Brilliant L. Detecting influenza epidemics using search engine query data. Nature 2009 Feb 19;457(7232):1012-1014. [doi: 10.1038/nature07634] [Medline: 19020500]

29. Wehner MR, Nead KT, Linos E. Correlation among cancer incidence and mortality rates and Internet searches in the United States. JAMA Dermatol 2017 Dec 01;153(9):911-914 [FREE Full text] [doi: 10.1001/jamadermatol.2017.1870] [Medline: 28658470]

30. Zink A, Rüth M, Schuster B, Darsow U, Biedermann T, Ständer S. Pruritus in Germany: A Google search engine analysis [Article in German]. Hautarzt 2019 Jan;70(1):21-28. [doi: 10.1007/s00105-018-4215-5] [Medline: 29876613]

31. Zink A, Schuster B, Rüth M, Pereira MP, Philipp-Dormston WG, Biedermann T, et al. Medical needs and major complaints related to pruritus in Germany: A 4-year retrospective analysis using Google AdWords Keyword Planner. J Eur Acad Dermatol Venereol 2019 Jan;33(1):151-156. [doi: 10.1111/jdv.15200] [Medline: 30067284 ]

32. Gesundheitsdaten. Berlin, Germany: Kassenärztliche Bundesvereinigung; 2017. Versorgungsgrade in den planungsbereichen URL: http://gesundheitsdaten.kbv.de/cms/html/17016.php [accessed 2018-10-12]

33. Lewis Z, George DN, Cowdell F, Holle H. Effects of short-term temperature change in the innocuous range on histaminergic and non-histaminergic acute itch. Acta Derm Venereol 2019 Feb 01;99(2):188-195 [FREE Full text] [doi: 10.2340/00015555-3077] [Medline: 30358890]

34. Deutscher Wetterdienst. Offenbach, Germany: Deutscher Wetterdienst Climate Data Center URL: https://cdc.dwd.de/portal/ 201904171234/index.html [accessed 2018-12-04]

35. Vocks E, Busch R, Fröhlich C, Borelli S, Mayer H, Ring J. Influence of weather and climate on subjective symptom intensity in atopic eczema. Int J Biometeorol 2001 Feb;45(1):27-33. [Medline: 11411412]

36. Augustin M, Wilsmann-Theis D, Körber A, Kerscher M, Itschert G, Dippel M, et al. Positionspapier: Diagnostik und therapie der xerosis cutis. J Dtsch Dermatol Ges 2018 Jul;16 Suppl 4:3-35. [doi: 10.1111/ddg.13580] [Medline: 29989340]

37. Umwelt Bundesamt. Current concentrations of air pollutants in Germany URL: https://www.umweltbundesamt.de/en/data/ current-concentrations-of-air-pollutants-in-germany\#/start?s=q64FAA==\& k=p5zoik [accessed 2018-10-11]

38. Google Ads. Keyword Planner: Reach the right customers with the right keywords URL: https://ads.google.com/intl/en/ home/tools/keyword-planner/ [accessed 2018-07-05] 
39. Statista. Die größten städte in Deutschland nach einwohnerzahl zum 31. Dezember 2017 URL: https://de.statista.com/ statistik/daten/studie/1353/umfrage/einwohnerzahlen-der-grossstaedte-deutschlands/ [accessed 2018-07-20]

40. Statistisches Bundesamt (Destatis). 2018. Migration. Integration. Regionen: Ausländeranteil URL: https://service.destatis.de/ DE/karten/migration_integration_regionen.html [accessed 2018-12-13]

41. Federal Institute for Research on Building, Urban Affairs and Spatial Development. Germany is growing - But not everywhere URL: https://www.bbsr.bund.de/BBSR/EN/Home/top-news/2018-germany-is-growing.html [accessed 2019-05-14]

42. Bundesamt für Kartographie und Geodäsie. Open Data - Freie daten und dienste des BKG URL: https://tinyurl.com/y8kwsu4d [accessed 2018-04-04]

43. Ling R, Lee J. Disease monitoring and health campaign evaluation using Google search activities for HIV and AIDS, stroke, colorectal cancer, and marijuana use in Canada: A retrospective observational study. JMIR Public Health Surveill 2016 Oct 12;2(2):e156 [FREE Full text] [doi: 10.2196/publichealth.6504] [Medline: 27733330]

44. Senecal C, Widmer R, Lerman L, Lerman A. Association of search engine queries for chest pain with coronary heart disease epidemiology. JAMA Cardiol 2018;3(12):1218-1221. [doi: 10.1001/jamacardio.2018.3459] [Medline: 30422176]

45. Alicino C, Bragazzi NL, Faccio V, Amicizia D, Panatto D, Gasparini R, et al. Assessing Ebola-related Web search behaviour: Insights and implications from an analytical study of Google Trends-based query volumes. Infect Dis Poverty 2015 Dec 10;4:54 [FREE Full text] [doi: 10.1186/s40249-015-0090-9] [Medline: 26654247]

46. Liu M, Chan M, Hsu C, Weng C, Yen T, Huang W. Association of uremic pruritus in hemodialysis patients with the number of days of high mean 24-hour particulate matter with a diameter of $<2.5 \mu \mathrm{m}$. Ther Clin Risk Manag 2017;13:255-262 [FREE Full text] [doi: 10.2147/TCRM.S129133] [Medline: 28260912]

47. Valdes-Rodriguez R, Mollanazar NK, González-Muro J, Nattkemper L, Torres-Alvarez B, López-Esqueda FJ, et al. Itch prevalence and characteristics in a Hispanic geriatric population: A comprehensive study using a standardized itch questionnaire. Acta Derm Venereol 2015 Apr;95(4):417-421 [FREE Full text] [doi: 10.2340/00015555-1968] [Medline: 25203328]

48. Grandhi R, He A, Semenov YR, Kwatra SG. Seasonal variation of itch: A study using real-time data from 2004 to 2016. J Am Acad Dermatol 2017 Mar;76(3):563-564. [doi: 10.1016/j.jaad.2016.09.046] [Medline: 28212763]

49. Bragazzi NL, Watad A, Brigo F, Adawi M, Amital H, Shoenfeld Y. Public health awareness of autoimmune diseases after the death of a celebrity. Clin Rheumatol 2017 Aug;36(8):1911-1917. [doi: 10.1007/s10067-016-3513-5] [Medline: 28000011]

50. Domnich A, Panatto D, Signori A, Lai PL, Gasparini R, Amicizia D. Age-related differences in the accuracy of Web query-based predictions of influenza-like illness. PLoS One 2015;10(5):e0127754 [FREE Full text] [doi: 10.1371/journal.pone.0127754] [Medline: 26011418]

\section{Abbreviations}

ANOVA: one-way analysis of variance

GP: general practitioner

OR: odds ratio

PM10: particulate matter 10 micrometers or less in diameter

Edited by G Eysenbach; submitted 18.02.19; peer-reviewed by E Papadavid, S Kardes; comments to author 08.05.19; revised version
received 24.05.19; accepted 04.06.19; published 12.07.19
Please cite as:
Tizek L, Schielein M, Rüth M, Ständer S, Pereira MP, Eberlein B, Biedermann T, Zink A
Influence of Climate on Google Internet Searches for Pruritus Across 16 German Cities: Retrospective Analysis
JMed Internet Res $2019 ; 21(7):$ e13739
URL: $\underline{\text { http://www.jmir.org/2019/7/e13739/ }}$
doi: $10.2196 / 13739$
PMID: $\underline{31301128}$

CLinda Tizek, Maximilian Schielein, Melvin Rüth, Sonja Ständer, Manuel Pedro Pereira, Bernadette Eberlein, Tilo Biedermann, Alexander Zink. Originally published in the Journal of Medical Internet Research (http://www.jmir.org), 12.07.2019. This is an open-access article distributed under the terms of the Creative Commons Attribution License (https://creativecommons.org/licenses/by/4.0/), which permits unrestricted use, distribution, and reproduction in any medium, provided the original work, first published in the Journal of Medical Internet Research, is properly cited. The complete bibliographic information, a link to the original publication on http://www.jmir.org/, as well as this copyright and license information must be included. 